\title{
An economic perspective
}

\section{PROF. JAN PETER BALKENENDE}

FORMER PRIME MINISTER OF THE NETHERLANDS, ERASMUS UNIVERSITY ROTTERDAM

In 1965, Dr Martin Luther King received an honorary degree from the VU Amsterdam. In a meeting with students at the Free University he said: 'I hope we can speed up that glad day when all of God's children - black men and white men, Protestants and Catholics, Muslims and Hindus, Jews and Gentiles - all of God's children will walk hand in hand, singing the old spiritual: Free at last, Free at last. Thank God Almighty, we are Free at last.' Dr King's remark was in line with the Four Freedoms of President Roosevelt: Freedom of Speech; Freedom of Worship; Freedom from Fear; and Freedom from Want. Freedom is always

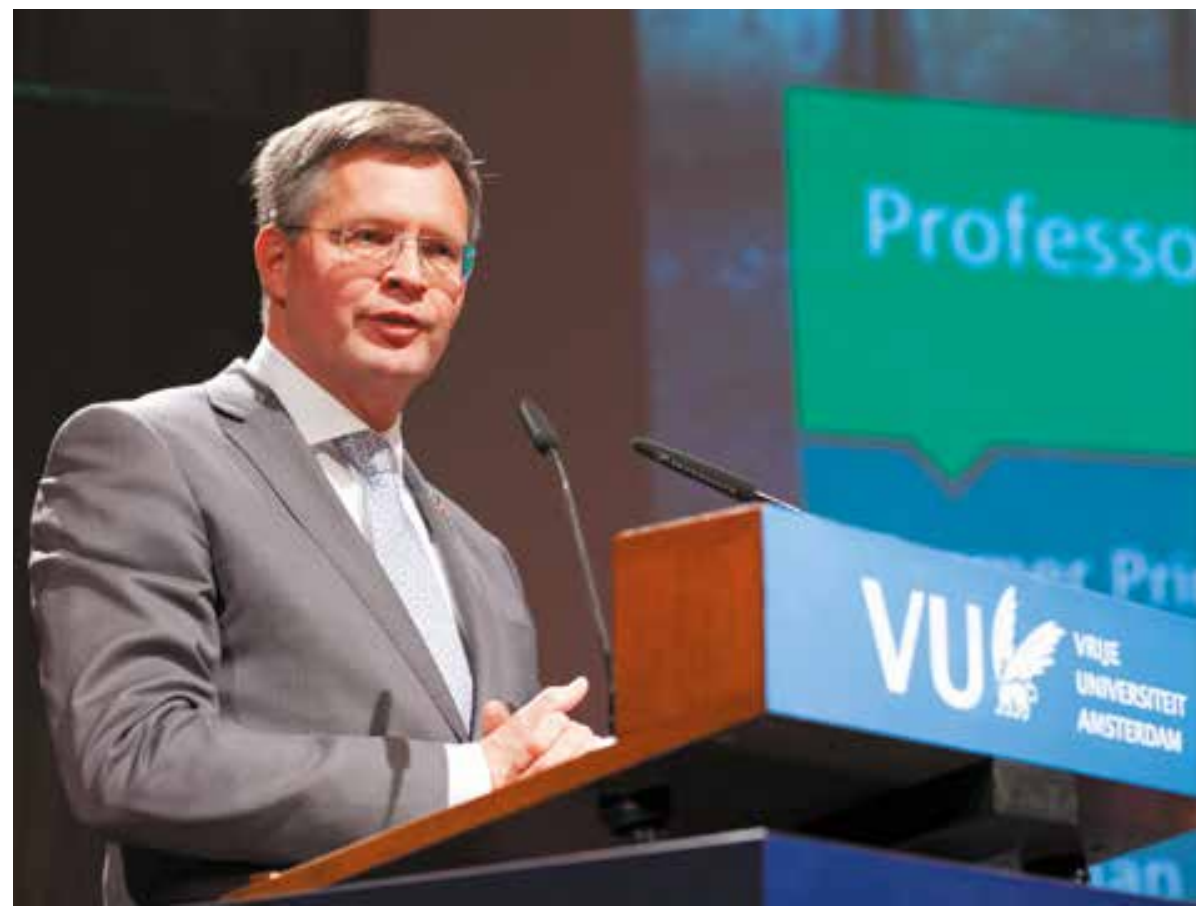


connected with responsibility. Choosing for freedom implies also choosing for a responsible society, taking care of others, and the natural environment, now and tomorrow.

Raising the right questions about societal developments, about the importance of human dignity, solidarity, and stewardship is key. Today, in the world of the new economy we constantly talk about 3 D. $3 \mathrm{D}$, Internet of Things, big data, robotics are symbols of this new economic model. Here, I share my personal take on the $3 \mathrm{D}$, those that are relevant for the quality of society: dignity, dialogue and development.

\section{Dignity}

Patriarch Bartholomew once said: 'The earth and humanity are created and intended to exist in a relationship of respect and harmony.' The Patriarch inspires us with this important remark. Indeed, reference was made to his views and insights in the famous Encyclical Laudato Si'. In Laudato Si, the Pope talks very clearly about our Common Home and the necessity to think in terms of Integral Ecology. Across the globe, people have subscribed to the importance of this Encyclical. The Patriarch and the Pope have given very clear and meaningful messages. They inspire the whole world.

Inspiration can also be derived from the UN's Sustainable Development Goals. These goals are about ensuring quality of life for every human being, in the world of today and the world of tomorrow. It is encouraging to see that, amidst tendencies of nationalism, populism, protectionism, violence, hate, and terrorism, the SDGs offer a positive agenda for the world: global goals, global language, and global solutions. The views of the Patriarch, the Pope and the SDGs - they all contribute to dignity for everyone.

\section{Dialogue}

Dignity, solidarity, taking care of others and God's creation implies the willingness to engage in meaningful dialogues. Chapter $\mathrm{V}$ of Laudato $S i$ deals with the importance of dialogue: for international, national, and local politics, transparency in decision-making processes, we need dialogue between politics and the economy, religions in dialogue with sciences. Good dialogues make societies, communities, economies, companies, organisations stronger.

Some years ago, I was invited to participate in a conference in Thailand hosted by the Caux Round Table, an organisation that focuses on the 
implementation of 'Moral Capitalism'. It was heartening to see people with different spiritual backgrounds at that conference - Roman Catholics, Protestants, Muslims, Hindus, Buddhists, Humanists - reflecting together on the question of how these different traditions can contribute to the implementation of the SDGs. It was an extremely inspiring example of having the right dialogue.

In the business sector - where I am active, alongside my role at the university - we can see that those companies that are willing to integrate sustainability into their business models will choose for meaningful stakeholder dialogues. It is necessary to invest in good dialogues. SDG number 17 is about partnerships. It is clear that the UN underlines the importance of dialogue and partnerships to realise the other I6 SDGs.

In this country - the Low Countries by the sea - we are used to the necessity to work together in order to keep our feet dry. The essence of the 'Polder model' is dialogue and cooperation. This orientation has proved to be relevant, not only for issues regarding water management, but also in other domains: social agreements, energy agreements, climate agreements, pension agreements.

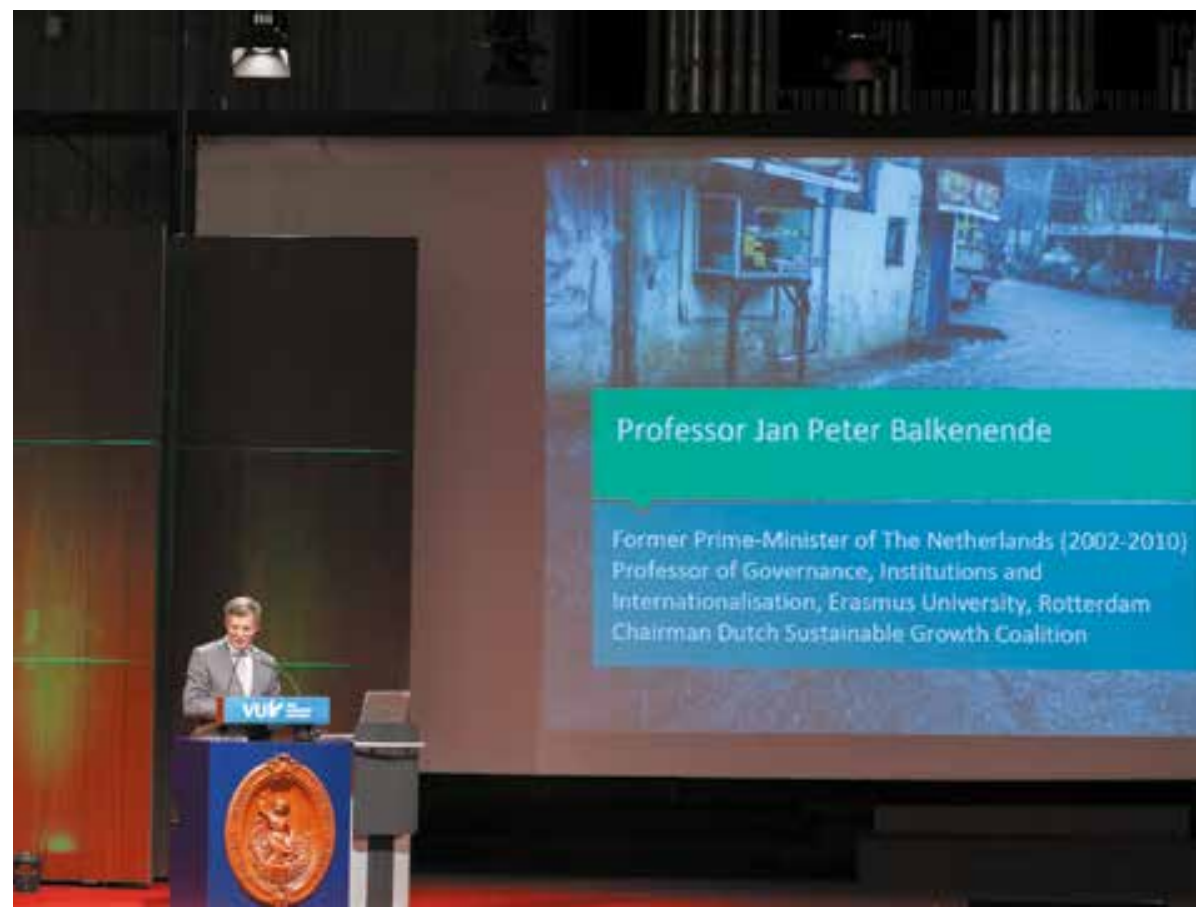




\section{Development}

Reflecting on dignity and having the right dialogue must have implications for development and must lead to concrete, practical results. Sometimes, we must act because of terrible circumstances. In 1953 , the Netherlands was confronted with a flood that took the lives of 1836 people, including members of my family. What happened in 1953 had a huge impact on policymaking in the Netherlands - taking the right policy measures. In the year 2000, the world embarked on the Millennium Development Goals. Fifteen years later, it could be concluded that 70 or $8 \circ$ per cent of these goals had been realised. The subsequent SDGs require concrete actions as well. Assessment tools are extremely important for analysing the progress we are making in the implementation of the SDGs.

It is good to see that universities, also those of applied sciences, are integrating the SDGs into their research and education programmes. Companies are rethinking their business models and business strategies. In the US, the Business Round Table published a 'Statement on the Purpose of a Corporation'. Following this statement, it is now a matter of execution. Cities are taking up their responsibilities with initiatives like $\mathrm{U}_{4}$ SSC, United for Smart, Sustainable Cities.

So, a values-driven dialogue is necessary. But which values are we talking about? What are the practical consequences of these values? How can common strategies be developed?

The founder of the Vrije Universiteit - the university where I studied, defended my PhD thesis, and where I became Professor of Christian Social Thought on Economy and Society - Dr Abraham Kuyper, made a very important remark at the First Christian Social Congress in I891, the year that also saw the publication of the Encyclical Rerum Novarum. Reflecting on the big societal issues of the nineteenth century, Kuyper said that an architectural critique of the structure of society was necessary. This remark is still relevant today. In fact, this is the message of His All-Holiness, of Laudato Si, and of the SDGs. 